\title{
Financial Literacy Of Sme's In Medan City: A Descriptive Analysis
}

\author{
Lisa Marlina \\ Department of Management, Faculty of Economics \\ and Business, \\ Universitas Sumatera Utara \\ Medan, Indonesia \\ lisamarlina143@yahoo.co.id
}

\author{
Nisrul Irawati \\ Department of Management, Faculty of Economics \\ and Business, \\ Universitas Sumatera Utara \\ Medan, Indonesia \\ nisrulirawati@yahoo.com
}

\begin{abstract}
There are a huge number of workers in Indonesia's SME sector almost $98 \%$ but this SME's sector give an enormous amount of contribution to Gross Domestic Product. On the contrary, SME's sector still has a low level of productivity and business performance. In order to perform well in business, every business should have a good management decision making. One of the important decision making in business is financial decision making which include the financial literacy. So this is the main objective of this study that is to measure SME's financial literacy based on questionnaire and self assessment. Data was collected using structured questionnaires from previous studied distributed to 60 SME's in Medan City.

The research's finding is indicative of SME's financial literacy in a very low level of financial literacy. In addition, based on SME's selfassessment test of financial literacy only a few of SME's able to assess themselves fairly and most of SME's are overestimate about their financial literacy.
\end{abstract}

Keywords: financial literacy; SME's; SelfAssesssment.

\section{INTRODUCTION}

The Indonesian economy is underpinned by Micro Small Medium Enterprises (SMEs) which absorb about $97 \%$ of the total national workforce and contribute 57\% of Gross Domestic Product (GDP). According to Law No. 20 of 2008 it is explained that SMEs are small companies owned and managed by a person or owned by a small group of people with a certain amount of wealth and income. Although indicators of contribution to the formation of Gross Domestic Product (GDP) and labor absorption increase, access of micro, small and medium enterprises (SMEs) to the global supply chain is very minimal. The contribution of SMEs in Indonesia to the global supply chain is only 0.8 percent. There are many reasons that SMEs in Indonesia still cannot enter the global market because one of the reason is the low level of financial literacy in Indonesia [1].

Based on Financial Services Authority (OJK) in Indonesia released the results of the national survey of Literacy and Financial Inclusion 2016. The survey was conducted in 2016, following the first survey in 2013. The result, Indonesia's financial literacy index in 2016 reached 29.66 percent, an increase compared to 21.84 percent in 2013 [2].

It means many of Indonesian people still faced the financial literacy problem because the lack of adequate financial literacy [3].

The lack of financial literacy can be a big problem for a country because the need for financial literacy is clear in both our personal lives and in business, but perhaps the highest stakes for personal financial adeptness is in micro- small business. Indonesia is still a developing country ceaselessly undertaking development in all fields aimed at promoting the welfare of society as mandated in the opening of the 1945 Constitution [4].

Therefore, it is the obligation of the Indonesian government to increase the financial literacy among the people especially the SME's. Financial literacy is seen as an important instrument for the success of small businesses, since it helps to understand and evaluate the information needed to make daily decisions that have financial impacts in companies' day-to-day management [5].

This is the main objective of this study which is to explore the financial literacy level of SME's around Medan City based on financial knowledge and financial self -assessment [6].

\section{LITERATURE REVIEW}

\section{A. Financial Literacy}

Mihalcova, Csikosova, and Antosova (2013) define financial literacy as the ability to use knowledge, skills and experience of a person to make effective decision regarding the use and management 
of his/her finance to provide life-long financial security for himself/herself and his/her family [7].

According to OECD (2014), financial literacy is knowledge and understanding of financial concepts and risks, and the skills, motivation and confidence to apply such knowledge and understanding in order to make effective decision across a range of financial contexts, to improve the financial well-being of individuals and society and to enable participation in economic life [8].

In developing the financial literacy questionnaire, this research adopted fundamental concepts lie at the root of saving and investment decisions as modelled in the life cycle setting. Three such concepts are: (i) numeracy and capacity to do calculations related to interest rates, such as compound interest; (ii) understanding of inflation; and (iii) understanding of risk diversification. Translating these into easily measured financial literacy metrics is difficult, but Lusardi and Mitchell (2008, 2011a, 2011b) have designed a standard set of questions around these ideas and implemented them in numerous surveys in the United States and abroad [9].

Based on the Banking Association of South Africa 2017: A financially-literate SME is one who: (i) has an adequate level of personal entrepreneurial competencies, personal finance skills, and business management skills; has an appropriate level of understanding of functional financial management systems; (ii) has an appropriate level of understanding of SME life-cycle funding and other financial services needs and options and knows where and how to source and negotiate those funding and service requirements; (iii) understands and can manage financial risks or seek relevant advice to manage such risks; (iv) understands legal, regulatory and tax issues as they relate to financial matters; (v) understands the range of legal recourses it can resort to when necessary, and namely, in case of bankruptcy or other situations of financial distress [10].

\section{B. Self Assessment}

Self-assessment is an evaluation of one's own abilities and failings. Wilson dan Jan (1998) comprehend the full meaning of self-assessment that is the monitoring of one's own levels of knowledge, performance, learning, abilities, thinking, behaviour and/or strategy use. It is about judging one's own performance. Self-assessment is neither a delineate of what has been done nor is it a program evaluation. It is an analysis of what has been done and the formation of a judgment or opinion of progress based on one's analysis [11].

Self-assessment can provide insight into one's true intellectual capacity and can help to identify gaps in ones' knowledge. Encouraging people to examine their own learning and levels of understanding can also be an important awake for identifying areas that require refinement [12].

Here, Self-assessment done by one's perception about their own financial literacy. Definition of "perception" is a belief or opinion, often held by many people and based on how things seem.(Cambridge Dictionary,2017). From SelfTheory Perception, Benn(1972), individual come to know their own attitudes, emotions and other internal states partially by inferring them from observations of their own overt behaviour and/or the circumstances in which this behaviour occurs [13].

\section{RESEARCH METODOLOGY}

The research was conducted in 6 sub-districts of Belawan sub-district, namely urban village of Medan I, Medan II urban village, Bagan Deli village, Kelurahan Kota Bahari, Kelurahan Kota Bahagia, and Medan Pulo Sicanang urban village. The object of the research is respondents are the perpetrators of SMEs in the village where the number of samples taken by judgment sampling Uma Sekaran (1992), the number of SMEs sample in the region determined as many as 60 SMEs.

\section{RESULT}

\section{A. Characteristic of Respondent}

TABLE I. RESPONDENT'S EDUCATIONAL BACKGOUND

\begin{tabular}{|l|l|l|}
\hline Educational Attainment & NOS & $\%$ \\
\hline Elementary School & 4 & $6.67 \%$ \\
\hline Middle School & 5 & $8.33 \%$ \\
\hline High School & 44 & $73.33 \%$ \\
\hline University & 7 & $11.67 \%$ \\
\hline Total & 60 & $100.00 \%$ \\
\hline \multicolumn{2}{|c|}{ Source: Author's Calculation (2017) }
\end{tabular}

The perpetrators of SMEs in Medan City generally have the latest education background at senior high school level $(73.33 \%)$. Only $11.67 \%$ of business actors with educational background are above senior high school level. This data indicates that many business actors have high school background or below. The world of work demands a high educational background in the selection process. People with a high school education level or below will find it difficult to find a job. Rarely do companies accept employees with high school education. Limitations of this opportunity can be the reason business actors start entrepreneurship to support his life. 
B. Respondents Based On Family Income Range

TABLE II. RESPONDENT'S FAMILY INCOME

\begin{tabular}{|l|l|l|}
\hline Income Range per Month & Total & \% \\
\hline$<$ Rp 2.500.000 & 13 & $21.67 \%$ \\
\hline Rp 2.500.000 s.d. Rp 5.000.000 & 26 & $43.33 \%$ \\
\hline$>$ Rp 5.000.000 & 21 & $35.00 \%$ \\
\hline Total & 60 & $100.00 \%$ \\
\hline \multicolumn{2}{|c|}{ Source: Author's Calculation (2017) }
\end{tabular}

Income level per month from the perpetrators of SMEs in the city of Medan is very diverse. From the available data, income levels are grouped into three categories. Earnings below Rp 2,500,000 indicate income levels that are below the minimum income for decent living, in the sense of meeting all basic needs. The results showed that there are $21.67 \%$ of business actors whose income is less than enough. The monthly cost range between $\mathrm{Rp} 2,500,000$ to $\mathrm{Rp}$ $5,000,000$ indicates a level of income called life sufficient, in the sense that all basic needs have been met and have income to save and other tertiary needs. $43.33 \%$ of business actors belong to this category. The remaining $35 \%$ of business actors have more than enough income.

\section{Respondents Based On Number Of Dependents}

TABLE III. NUMBER OF DEPENDENTS

\begin{tabular}{|l|l|l|}
\hline Number of Dependents & Total & $\%$ \\
\hline 0-2 People & 30 & $50.0 \%$ \\
\hline 3-6 People & 29 & $48.3 \%$ \\
\hline$>$ 6 People & 1 & $1.7 \%$ \\
\hline Total & 60 & $100.0 \%$ \\
\hline \multicolumn{2}{|c|}{ Source : Author's Calculation (2017) } \\
\hline
\end{tabular}

Business actors in Medan generally have dependents $0-2$ people $(50 \%)$ or 3-6 people $(48.3 \%)$. Some of business actors decide to take care for their family members who dependent on them. Most of the business actors have more than 3 children so the dependents per head of household reach a high enough rate for dependents of 3 to 6 people $(48.3 \%)$.

\section{Financial Literacy}

TABLE IV. FINANCIAL LITERACY LEVEL

\begin{tabular}{|l|l|l|}
\hline Financial Literacy & NOS & $\%$ \\
\hline Very Low & 52 & $86.67 \%$ \\
\hline Low & 7 & $11.67 \%$ \\
\hline Moderate & 1 & $1.67 \%$ \\
\hline High & 0 & $0.00 \%$ \\
\hline
\end{tabular}

TABLE IV. Cont

\begin{tabular}{|l|l|l|}
\hline Very High & 0 & $0.00 \%$ \\
\hline Total & 60 & $100.00 \%$ \\
\hline \multicolumn{2}{|c|}{ Source: Author's calculation (2017 }
\end{tabular}

Financial literacy ability of business actors is measured using eight questions about financial skills. Each correct answer will be given a score of 1 and that is not accurately given a score of 0 . Financial literacy ability is measured based on the final score of financial literacy indicators. A score of $0-1$ is a very low category of financial literacy ability. A 2-3 score belongs to the low category. A score of 4-5 is classified as moderate or sufficient. Scores 6-7 are high. Score 8 is categorized as very high.

Evaluation of respondents' answers indicates that the majority of respondents have very low literacy ability $(86.67 \%)$ or low $(11.67 \%)$. The rest, as much as $1.67 \%$ is sufficient. No business actor reaches the high or very high literacy category. The majority of respondents answered correctly about the appropriate sources of income for the age range 2035 years (58.33\%). Furthermore, only $18.33 \%$ correctly answer the benefits of business insurance. No respondents answered correctly on questions about the source of credit worthiness evaluations of SME's actors.

\section{E. Financial Literacy Self-Assessment}

TABLE V. SELF-ASSESSMENT LEVEL

\begin{tabular}{|l|l|l|}
\hline $\begin{array}{l}\text { Compatible Self-Assessment on Financial } \\
\text { Literacy }\end{array}$ & Amount & $\%$ \\
\hline $\begin{array}{l}\text { Compatible Self-Assessment on Financial } \\
\text { Literacy }\end{array}$ & 23 & $38.33 \%$ \\
\hline $\begin{array}{l}\text { Not Compatible Self-Assessment on Financial } \\
\text { Literacy }\end{array}$ & 37 & $61.67 \%$ \\
\hline Total & 60 & $100 \%$ \\
\hline
\end{tabular}

This research provides self-assessment for financial literacy ability of SMEs in Medan City. In this case, as many as $38.33 \%$ of the respondents are able to assess their financial literacy skills correctly which they have.

Among the $61.67 \%$ of SMEs that have not yet measured their ability correctly, as much as $58.33 \%$ tend to overestimate their ability. The rest, $3.33 \%$ of business actors actually lowered on the financial literacy they have.

\section{ANALYSIS AND DISCUSSION}

The essence of financial literacy is ability to make informed and substantiated decisions regarding personal finances often it related to such question as how to spend the money, where and how to store the 
money, where to invest the money and how money. (OECD, 2013).

As this to multiply the study found that SME's actors in Medan City still have a low level of financial literacy, it means that they have insufficient knowledge and understanding the financial concepts. The result of this research is supported by Plakalovic (2015) which done a research with the conclusion that managers and owners of SME's in Republic Srpska had a low level of basic financial knowledge. Also, Fatoki (2014) in South Africa found that the owners of new micro-enterprises have a low level of financial literacy.

Based on the financial literacy self -assessment, the majority of SME"s cannot evaluate their financial literacy correctly. This implies that SME's had nonstandard belief. Some of the SME's have overconfidence in financial literacy that they overestimate of their own ability and both underestimate of their own weaknesses. In other word, if SME's overestimate in their own selfassessment, it seems that SME's will take excessive risk in finance.

\section{CONCLUSION AND RECOMMENDATION}

The research provides a general capture of financial literacy of SME's in Medan City. Based on the research result, the SME's actors in Medan City have a low level of financial literacy. But, the SME's actors still could not do the self-assessment to judge their own knowledge in financial. There is unclear understanding of SME's perception about their financial literacy compare to the level of financial literacy they have. They seem feel that they have a financial knowledge but in fact that they do not have enough knowledge of financial literacy concepts.

Therefore, the research recommend that government institution should learn about the specific character, specific behavior, specific condition or specific environment of each location of SME's with applying local wisdom in making a proper financial literacy program.

\section{ACKNOWLEDGMENT}

The authors gratefully thank and acknowledge that this present research is supported by University of Sumatera Utara. The support is under the research grant TALENTA of Year 2017.

\section{REFERENCES}

[1] Aprea, Camela, Eveline Wuthe Klaus Breuer, Noi Keng Koh, Peter Bettina, Grimel-Fuhrman, Jane Slopus (2016), Internatinational Handbook of Financial Literacy, Springer, ISBN 978-981-10-0360-8 (e-book).

[2] Benn, Daryl J, (1972), Self-Perception Theory, Stanford University, California, Academic Press Inc. New York and London.

[3] Fatoki Olawale (2014) The Financial Literacy of Micro Entrepreneurs in South Africa J Soc Sci, 40(2): 151-158 (2014)@ Kamla-Raj 2014

[4] Kemenperin Indonesia :www.kemenperin.go.id/artikel/14200/Kontribusi-UMKMNaik

[5] Lusardi, Annamaria, Punam Anand Keller, and Adam M. Keller. (2008). "New Ways to Make People Save: A Social Marketing Approach." In Overcoming the Saving Slump: How to Increase the Effectiveness of Financial Education and Saving Programs, edited by Annamaria Lusardi, 20936. Chicago and London: University of Chicago Press.

[6] Lusardi, Annamaria, and Olivia S. Mitchell. (2011a). "Financial Literacy and Planning: Implications for Retirement Well-Being.” In Financial Literacy: Implications for Retirement Security and the Financial Marketplace, edited by Olivia S. Mitchell and Annamaria Lusardi, 17-39. Oxford and New York: Oxford University Press.

[7] Lusardi, Annamaria, and Olivia S. Mitchell. (2011b). "Financial Literacy around the World: An Overview." Journal of Pension Economics and Finance10 (4): 497-508.

[8] Mihalcova, B., Csikosova, A., and Antosova, M., (2013). Financial literacy - the urgent need today. Procedia - Social and Behavioral Sciences, 109 (2014), pp. 317-321.

[9] OJK (2016) : http:// www.ojk.go.id

[10] OECD (2013, 2014) http:// www.oecd.org/ /Financial_SME_Survey_ENG.pdf

[11] Plakalović, Novo (2015) Financial Literacy of SME's Managers, Managing Intellectual Capital and Innovation for Sustainable and Inclusive Society 27-29 May 2015, Bari, Italy. Managment knowledge and Learning, joint InternationaI Conference 2015, Technology Innovation and Industrial Management.

[12] Sekaran, Uma and Roger Bougie, (2013): Research Methods for Business: A Skill Building Approach, 6 th Edition, Wiley.

[13] The Cambridge Advanced Learner's Dictionary \& Thesaurus (C) Cambridge University Press) (2017)

[14] Wilson, Jeni and Leslie Wing Jan, (1998) Self Assessment for Students: Proformas and Guidelines. Armadale: Eleanor Curtain Publishing, 